\title{
Synthesis of Xanthones, Thioxanthones and Acridones by the Coupling of Arynes and Substituted Benzoates
}

\author{
Jian Zhao and Richard C. Larock \\ Department of Chemistry, lowa State University, Ames, IA 50011, larock@iastate.edu
}

\begin{abstract}
The reaction of silylaryl triflates, $\mathrm{CsF}$ and ortho heteroatom-substituted benzoates affords a general and efficient way to prepare biologically-interesting xanthones, thioxanthones and acridones. This chemistry presumably proceeds by a tandem intermolecular nucleophilic coupling of the benzoate with an aryne and subsequent intramolecular electrophilic cyclization.
\end{abstract}

\section{Introduction}

Xanthones are secondary metabolites found in higher plant families, fungi and lichens. ${ }^{1}$ This class of compounds exhibits interesting pharmaceutical properties; specifically, anti-bacterial, anti-inflammatory, anti-cancer, and anti-viral activities have been observed. ${ }^{2}$ Some xanthonecontaining plants, for example, cratoxylum cochinchinense (Lour.) Blume, have been used as traditional medicines to treat fever, coughing, diarrhea, itching, ulcers and abdominal complaints. ${ }^{3}$ Thioxanthone derivatives also exhibit interesting anti-cancer activities. ${ }^{4}$ Xanthones are usually synthesized through the intermediacy of benzophenones or diaryl ethers under harsh reaction conditions and/or in the presence of strong acids or toxic metals. 5 Acridones are naturally-occurring compounds exhibiting a variety of biological activities. They are important anti-leishmanial, anti-fungal, anti-tumor and DNA-intercalating anti-cancer drugs. ${ }^{6}$ Acridones are usually prepared by the acid-induced ring closure of $N$-phenyl anthranilic acids, which are usually obtained from Ullmann condensation of anilines with ortho halogen-substituted benzoic acids. However, harsh reaction conditions and tedious workup procedures are generally required. ${ }^{7}$ An efficient and general synthesis of each of these heterocycles is thus highly desirable. 
<smiles>[R]c1c([R])c([R])c(C(=O)c2c([Y])c([R6])c([R6])c([R7])c2[R7])c([R7])c1[R]</smiles>

\section{$\mathrm{X}=\mathrm{O} \quad$ Xanthones $X=S \quad$ Thioxanthones $X=N R \quad$ Acridones}

Benzyne, a highly reactive intermediate, was first proposed by Wittig in $1942,{ }^{8}$ and the structure was confirmed by Roberts in 1956 using ${ }^{14} \mathrm{C}$ isotope labeling. ${ }^{9}$ Since then, many methods have been developed to generate benzynes, for example, the base-promoted elimination of hydrogen halide from aryl halides, ${ }^{10}$ the elimination of $o$-dihaloaromatics with lithium amalgam or magnesium, ${ }^{11}$ or the recently reported decomposition of 2-magnesiated aryl sulfonates. ${ }^{12}$ In 1983, Kobayashi first reported a novel way to generate arynes from silylaryl triflate precursors in the presence of $\mathrm{CsF} .{ }^{13}$ Later, nucleophiles bearing neighboring electrophiles, such as ureas, ${ }^{14}$ trifluoroacetanilides and sulfinamides,, 15 and $\beta$-keto esters 16 have been shown to react with these aryne precursors to afford the $\mathrm{C}-\mathrm{N}$ bond or $\mathrm{C}-\mathrm{C}$ bond insertion products (Scheme 1). These nucleophiles first undergo intermolecular nucleophilic attack on the aryne. Subsequent intramolecular electrophilic cyclization, followed by fragmentation, affords the final insertion product.

Recently, we communicated a novel annulation reaction utilizing readily accessible salicylates and silylaryl triflates plus CsF, which affords an efficient one-step synthesis of biologicallyinteresting xanthones and thioxanthones (eq. 1). ${ }^{17}$ This chemistry presumably proceeds by a tandem intermolecular nucleophilic coupling of the benzoate and aryne, and subsequent intramolecular electrophilic cyclization. A fragmentation step, which is inevitable in the insertion examples, is not involved in this annulation process, because the intermediate obtained from the cyclization is a stable 6-membered ring system. Herein, we provide a full account of this efficient synthesis of xanthones and thioxanthones, plus, we also wish to report an extension of this coupling-cyclization strategy to the synthesis of biologically-interesting acridones.

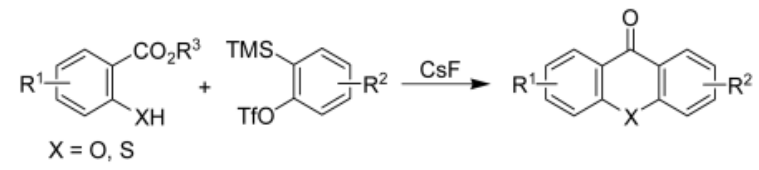

(1).

\section{Results and Discussion}

Optimization Studies

The reaction of methyl salicylate (1a) and the commercially available aryne precursor $o$ (trimethylsilyl)phenyl triflate (2a) was first conducted in the presence of 4 equiv of $\mathrm{CsF}$ in 5 
$\mathrm{mL}$ of $\mathrm{MeCN}$. After $12 \mathrm{~h}$ reaction at room temperature, an $80 \%$ combined yield of methyl 2phenoxybenzoate (3a) and xanthone (4a) was obtained in a 40:60 ratio (Table 1, entry 1). Presumably, this reaction proceeds through the key intermediate $\mathbf{B}$ generated by nucleophilic coupling of the aryne and the aryloxide $\mathbf{A}$ (Scheme 2). The carbanion $\mathbf{B}$ can either undergo $\mathbf{H}$ abstraction to afford benzoate 3a or intramolecular electrophilic cyclization to generate the xanthone (4a). The major problem here is the proton abstraction process, which could be suppressed by adjusting the reaction conditions, for example, using different solvents and concentrations. Thus, we next conducted the coupling-cyclization reaction in acetone, and a $75 \%$ yield of diaryl ether 3a and xanthone (4a) was obtained in a 38:62 ratio (entry 2), which suggests that a less polar solvent should be examined. We then performed the reaction in $\mathrm{CH}_{2} \mathrm{Cl}_{2}$. However, only a trace of the xanthone (4a) was observed by GC-MS analysis after $24 \mathrm{~h}$ (entry 3). When THF was used as the solvent at room temperature, after $24 \mathrm{~h}$ reaction, a $20 \%$ yield of products $\mathbf{3 a}$ and $\mathbf{4 a}$ was obtained, and a lot of the starting materials $\mathbf{1 a}$ and $\mathbf{2 a}$ was observed by GC-MS analysis. However, the ratio of 3a to $4 \mathbf{a}$ was 5:95, suggesting that proton abstraction has been almost completely suppressed (entry 4). When this reaction was conducted in toluene, only a trace of the product was evident by GC-MS analysis (entry 5). $\mathrm{MeNO}_{2}$ also turned out to be an unsuitable solvent for this reaction (entry 6). At this point, THF seemed to be the best solvent, at least as far as the reaction selectivity was concerned. The same reaction was then carried out at $65{ }^{\circ} \mathrm{C}$ in THF for $24 \mathrm{~h}$. A $75 \%$ yield of xanthone (4a) was isolated by flash chromatography and GC-MS analysis indicated only a trace of the diaryl ether 3a was obtained (entry 7). Further investigation indicated that a reaction temperature of $90^{\circ} \mathrm{C}$ or $50^{\circ} \mathrm{C}$ reduces the amount of xanthone product (entries 8 and 9). When DME was used as the solvent, the reaction afforded only a $70 \%$ yield of two isomers formed in a 25:75 ratio (entry 10$)$.

The effect of the fluoride source has also been examined in this process. When tetrabutylammonium fluoride (TBAF) was used as the fluoride source, the reaction proceeded much faster. After $3 \mathrm{~h}$, all of the starting materials were consumed and the proton abstraction product 3a predominated (entry 11). A 65\% yield of an 8:92 ratio of 3a and 4a was obtained when this reaction was carried out in the presence of 2 equiv of $\mathrm{CsF}$ (entry 12). In conclusion, the "optimal" reaction conditions for this one-step synthesis of xanthone utilize 4 equiv of CsF in THF solvent at $65^{\circ} \mathrm{C}$ for $24 \mathrm{~h}$ (entry 7).

\section{Synthesis of Xanthones}

Employing our "optimal" reaction conditions, we have investigated the reaction scope and limitations of this process. These results are summarized in Table 2. We first examined the effect of a methoxy substituent on the salicylate ring to determine which position on the salicylate ring affords the best yield of xanthone. Thus, salicylates $\mathbf{1 b}, \mathbf{1 c}, \mathbf{1 d}$ and $\mathbf{1 e}$ were employed, and 35-69\% yields of substituted xanthones $\mathbf{4 b - 4 e}$ were obtained (entries 2-5). Having an electron-donating methoxy group in the 5 position of the salicylate ring gave the highest yield (entry 4). The yields of xanthones from the 3-and 4-methoxy starting materials were only slightly lower, but the 6-methoxy isomer gave a much lower yield. When methyl 5acetylsalicylate (1f) with an electron-withdrawing group in the 5 position was used as the starting material, a 58\% yield of xanthone $\mathbf{4 f}$ was isolated by flash chromatography (entry 6). On the other hand, the reaction of methyl 5-fluorosalicylate (1g) and aryne precursor $2 \mathbf{a}$ affords an $83 \%$ yield of xanthone $\mathbf{4 g}$ (entry 7 ). The reaction of methyl 5-bromosalicylate (1h) with aryne $\mathbf{2 a}$ affords a $75 \%$ yield of the product $\mathbf{4 h}$ (entry 8). The phenyl- and methyl-substituted salicylates $\mathbf{1 i}$ and $\mathbf{1 j}$ afforded $64 \%$ and $71 \%$ yields of the corresponding xanthone products respectively (entries 9 and 10). When methyl 5-hydroxysalicylate (1k) is allowed to react with 2.5 equiv of aryne precursor $\mathbf{2 a}$, the $O$-arylated xanthone product $\mathbf{4 k}$ was isolated in a $52 \%$ yield (entry 11). We have previously reported the facile arylation of phenols by these same aryne precursors. ${ }^{18}$ From these results with 5 -substituted salicylates, there is no obvious 
correlation between the electronic properties of the substituent and the yield. Phenyl salicylate (11) has been employed in this reaction and an $81 \%$ yield of xanthone 4a was obtained (entry 12). Assuming that 2-hydroxybenzoic acid would first form the corresponding phenyl ester 11, 18 which should then afford the corresponding xanthone (4a), we treated 2 equiv of benzyne precursor 2a and 2-hydroxybenzoic acid (1m) in the usual fashion. Unfortunately, none of the desired product was observed for reasons we do not really understand at this time (entry 13). Interestingly, the cross coupling of methyl 1-hydroxy-2-naphthoate (1n) with silylaryl triflate 2a affords a 73\% yield of xanthone $\mathbf{4 l}$, but the reaction using methyl 2-hydroxy-3-naphthoate (1o) only generates a $48 \%$ yield of the product $\mathbf{4 m}$ (entries 14 and 15 ). This latter reaction produced several side products which have not been identified. The annulation of $\mathbf{1 p}$, which contains a pyridine ring, afforded none of the xanthone product under our "optimal" conditions (entry 16). Again, we are uncertain why this latter reaction failed.

After investigating the effect of varying the salicylate structure, we examined the reaction efficiency using different aryne precursors (Scheme 3). A 62\% yield of a single isomeric methoxyxanthone $4 \mathbf{e}$ was obtained from the reaction of methyl salicylate 1a with aryne precursor $\mathbf{2 b}$ after $24 \mathrm{~h}$ at $90^{\circ} \mathrm{C}$ (entry 17). Note that a somewhat higher temperature was required to get a good yield. The regioselectivity of this reaction is due to the steric and electronic effects in the step involving nucleophilic attack on the aryne, which has been seen in several previous reactions involving this aryne. ${ }^{18}$ When the dimethoxysilylaryl triflate $\mathbf{2 c}$ was employed, a 57\% yield of xanthone $\mathbf{4 0}$ was isolated (entry 18). Again a higher temperature was required. The reaction of aryne precursor $\mathbf{2 d}$ with methyl salicylate (1a) afforded a $51 \%$ yield of xanthone $\mathbf{4 p}$ (entry 19). When aryne precursor $2 \mathbf{e}$ was employed, a 59\% yield of two isomeric xanthones $\mathbf{4} \mathbf{j}$ and $\mathbf{4 q}$ was obtained in a 1:1 ratio (entry 20). This is consistent with the intermediacy of an unsymmetrical methyl-substituted benzyne. Aryne precursor $\mathbf{2} \mathbf{f}$ afforded a $45 \%$ yield of a single xanthone product $\mathbf{4 r}$ (entry 21 ).

One of the major advantages of this methodology is that halogen atoms can be tolerated, which provides access to more structurally diverse xanthone skeletons via metal-catalyzed crosscoupling reactions. As illustrated in Scheme 4, the halogen-substituted xanthone product $\mathbf{4 h}$ can be further modified by Heck ${ }^{19}$ and Suzuki ${ }^{20}$ reactions, affording interesting xanthone derivatives $\mathbf{5 a}$ and $\mathbf{5 b}$ for further biological examination.

\section{Synthesis of Thioxanthones}

Biologically-interesting thioxanthone derivatives have also been prepared by this same methodology. All of the results are summarized in Table 3. Methyl thiosalicylate (6a) and 1.1 equiv of benzyne precursor $2 \mathrm{a}$ were treated with 4 equiv of $\mathrm{CsF}$ in $5 \mathrm{~mL}$ of THF at $65^{\circ} \mathrm{C}$, after $24 \mathrm{~h}$, a $35 \%$ yield of thioxanthone (7a) was isolated. The lower yield in this example is presumably due to oxidative homocoupling of the thiols, since thiols are known to afford disulfides in the presence of CsF on a celite solid support in air. ${ }^{21}$ In order to suppress this undesired homocoupling process, the same reaction was repeated under an $\mathrm{Ar}$ atmosphere, and a 55\% yield of thioxanthone (7a)was obtained. Further optimization indicated that a $64 \%$ yield of product 7a could be obtained under more dilute conditions, although a small amount of disulfide product and $S$-arylation product were present (Table 3, entry 1 ). The reaction of this thiol with benzyne precursor $\mathbf{2 b}$ afforded a $45 \%$ yield of the desired thioxanthone $\mathbf{7 b}$ (entry 2). When $\mathbf{2 d}$ was employed as the aryne precursor in this reaction, a $40 \%$ yield of the product $\mathbf{7 c}$ was isolated (entry 3 ). The reaction of $\mathbf{2 e}$ afforded a $56 \%$ yield of two regioisomers $\mathbf{7 d}$ and $\mathbf{7 e}$ in a 1:1 ratio (entry 4). Finally, aryne precursor $\mathbf{2 f}$ was allowed to react with thiosalicylate 6a, and a $62 \%$ yield of thioxanthone $7 \mathbf{f}$ was isolated by flash chromatography (entry 5 ). 


\section{Synthesis of Acridones}

After we had a general and efficient synthesis of xanthones and thioxanthones in hand, we attempted to expand this methodology to the synthesis of acridones, a well-known class of anti-fungal, anti-tumor and anti-cancer compounds. ${ }^{6}$ Acridones have been prepared by the coupling of 3-halogeno-4-methoxybenzynes generated from 5-(3-halogeno-4-methoxyphenyl) thianthrenium perchlorates and LDA in THF at reflux with 2-aminobenzoate. ${ }^{22}$ However, this protocol employs a fairly unusual aryne precursor, and it also suffers from the moisturesensitive reagents and conditions. Methyl 2-aminobenzoate (8a) was first prepared and allowed to react with aryne precursor $2 \mathbf{a}$, and a 50\% yield of the acridone product $9 \mathbf{a}$ was obtained (Table 4, entry 1). Methyl 2-( $N$-methylamino)benzoate $(\mathbf{8 b})$ was then allowed to react with aryne precursor $\mathbf{2 a}$. After 1 day of reaction, a $72 \%$ yield of acridone $\mathbf{9 b}$ was isolated by flash chromatography (entry 2$)$. However, the reaction employing methyl 2-( $N$-phenylamino) benzoate (8c) was very sluggish; after 2 days of reaction, only a $7 \%$ yield of the desired product 9c was observed by GC-MS analysis. The low yield is presumably due to the steric hindrance introduced by the presence of the phenyl substituent (entry 3). Interestingly, the reaction of methyl 2-(N,N-dimethylamino)benzoate (8d) affords a $65 \%$ yield of acridone product $\mathbf{9 b}$, which indicates that even tertiary amines can be successfully employed in this transformation (entry 4). Apparently the anticipated ammonium-containing product undergoes demethylation under the reaction conditions. Several halogen-substituted benzoates $(\mathbf{8 e - 8 g})$ have also been prepared from the corresponding acids and employed in this process (entries 5-7). Yields of 48-71\% of the corresponding acridone products (9d-9f) have been obtained. We have not employed protecting groups on nitrogen since that could well lead to $\mathrm{C}-\mathrm{N}$ insertion products. 14,15

At this point, we examined the effect of the aryne structure on the yield of acridone. When silylaryl triflate $\mathbf{2 b}$ was employed with benzoate $\mathbf{8 b}$, the reaction was very sluggish and only a trace amount of the desired acridone product $9 \mathrm{~g}$ was observed by GC-MS analysis (entry 8). Aryne precursor $\mathbf{2 d}$ afforded only a $27 \%$ yield of the product $\mathbf{9 h}$ and this reaction had to be run at $90{ }^{\circ} \mathrm{C}$ (entry 9). The reaction of aryne precursor $\mathbf{2 e}$ with benzoate $8 \mathbf{a}$ afforded a $51 \%$ yield of two isomeric acridones, $\mathbf{9 i}$ and $\mathbf{9 j}$, in a 1:1 ratio (entry 10). A $35 \%$ yield of acridone product 9k was obtained when aryne precursor $\mathbf{2 f}$ was employed (entry 11). These last two reactions also had to be run at $90{ }^{\circ} \mathrm{C}$.

A plausible mechanism for these aminobenzoate reactions is proposed in Scheme 4. The benzoate bearing an amino group presumably first undergoes nucleophilic attack on the aryne generated in situ from the silylaryl triflate. When $\mathrm{R}$ is a proton, the actual nucleophile involved could be either the neutral amine or the anionic intermediate $\mathbf{D}$ generated by hydrogen abstraction from the amine by CsF. However, when the tertiary amine $\mathbf{8 d}$ is employed, although no proton is available for abstraction, this reaction still works well, suggesting that the neutral amine itself is nucleophilic enough for this transformation. Therefore, the reaction mechanism which proceeds via intermediates $\mathbf{F}$ and $\mathbf{G}$ seems more likely, although we cannot rule out possible anionic nucleophilic attack on the aryne, which proceeds via intermediates $\mathbf{D}$ and $\mathbf{E}$. Subsequent intramolecular cyclization should afford the final acridone products.

\section{Conclusions}

A general one-pot synthesis of biologically-interesting xanthones, thioxanthones and acridones has been developed. This chemistry presumably proceeds by a tandem intermolecular nucleophilic coupling of the substituted benzoates and arynes and subsequent intramolecular electrophilic cyclization. The mild reaction conditions and generally high reaction efficiency provide advantages over previously reported multi-step procedures. In generally, this strategy tolerates both electron-donating and electron-withdrawing functionalities on the benzoate ring, but substituents on the aryne ring appear to lower the yields of the desired products. 


\section{Experimental Section}

\section{Representative procedure for the coupling-cyclization of arynes and salicylates}

$\mathrm{CsF}(1.0 \mathrm{mmol})$, the salicylate $(0.25 \mathrm{mmol})$, and the silylaryl triflate $(0.28 \mathrm{mmol})$ in $5 \mathrm{~mL}$ of anhydrous THF were stirred at 65 or $90{ }^{\circ} \mathrm{C}$ for $24 \mathrm{~h}$. The reaction mixture was allowed to cool to room temperature, diluted with diethyl ether $(25 \mathrm{~mL})$ and washed with brine $(25 \mathrm{~mL})$. The aqueous layer was re-extracted with diethyl ether $(2 \times 25 \mathrm{~mL})$. The organic layers were combined, dried $\left(\mathrm{MgSO}_{4}\right)$, filtered, and the solvent was removed under reduced pressure. The residue was purified by flash chromatography on silica gel. $9 H$-Xanthen-9-one (4a). ${ }^{1} \mathrm{H}$ NMR $\left(\mathrm{CDCl}_{3}\right) \delta 7.37(\mathrm{t}, J=6.0 \mathrm{~Hz}, 2 \mathrm{H}), 7.48(\mathrm{~d}, J=6.4 \mathrm{~Hz}, 2 \mathrm{H}), 7.70-7.74(\mathrm{~m}, 2 \mathrm{H}), 8.33(\mathrm{dd}, J=$ 6.0, $1.2 \mathrm{~Hz}, 2 \mathrm{H}) ;{ }^{13} \mathrm{C}$ NMR $\left(\mathrm{CDCl}_{3}\right)$ 118.2, 122.1, 124.1, 126.9, 135.0, 156.4, 177.4; IR $\left(\mathrm{CDCl}_{3}\right) 2914,2874,1654,1456 \mathrm{~cm}^{-1}$; HRMS m/z 196.0527 (calcd for $\mathrm{C}_{13} \mathrm{H}_{8} \mathrm{O}_{2}, 196.0524$ ).

\section{Representative procedure for the coupling-cyclization of arynes and thiosalicylates}

$\mathrm{CsF}(1.0 \mathrm{mmol})$, the thiosalicylate $(0.25 \mathrm{mmol})$ and the silylaryl triflate $(0.28 \mathrm{mmol})$ were added to $10 \mathrm{~mL}$ of anhydrous THF, and the reaction vial was flushed with Ar. The whole reaction solution was then stirred at 65 or $90^{\circ} \mathrm{C}$ for $24 \mathrm{~h}$ and worked up as described previously. 9H-Thioxanthen-9-one (7a). ${ }^{1} \mathrm{H} \mathrm{NMR}\left(\mathrm{CDCl}_{3}\right) \delta 7.48(\mathrm{td}, J=6.7,1.5 \mathrm{~Hz}, 2 \mathrm{H}), 7.56-7.65(\mathrm{~m}$, $4 \mathrm{H}), 8.62(\mathrm{dd}, J=7.4,0.8 \mathrm{~Hz}, 2 \mathrm{H}) ;{ }^{13} \mathrm{C} \mathrm{NMR}\left(\mathrm{CDCl}_{3}\right) 126.2,126.5,129.4,130.1,132.5,137.5$, 180.2; IR $\left(\mathrm{CDCl}_{3}\right) 2971,2919,1684,1459 \mathrm{~cm}^{-1} ; \mathrm{HRMS} \mathrm{m} / \mathrm{z} 212.0299$ (calcd for $\mathrm{C}_{13} \mathrm{H}_{8} \mathrm{OS}$, 212.0296).

\section{Representative procedure for the coupling-cyclization of arynes and 2-aminobenzoates}

$\mathrm{CsF}(1.0 \mathrm{mmol})$, the 2 -aminobenzoate $(0.25 \mathrm{mmol})$, and the silylaryl triflate $(0.28 \mathrm{mmol})$ in $10 \mathrm{~mL}$ of anhydrous THF were stirred at 65 or $90^{\circ} \mathrm{C}$ for $24 \mathrm{~h}$. The reaction mixture was allowed to cool to room temperature, diluted with ethyl acetate $(25 \mathrm{~mL})$ and washed with brine $(25$ $\mathrm{mL})$. The aqueous layer was re-extracted with ethyl acetate $(2 \times 25 \mathrm{~mL})$. The organic layers were combined, dried $\left(\mathrm{MgSO}_{4}\right)$, filtered, and the solvent was removed under reduced pressure. The residue was purified by flash chromatography on silica gel. 10-Methyl-10H-acridin-9one (9b). ${ }^{1} \mathrm{H}$ NMR $\left(\mathrm{CDCl}_{3}\right) \delta 3.88(\mathrm{~s}, 3 \mathrm{H}), 7.28(\mathrm{t}, J=7.2 \mathrm{~Hz}, 2 \mathrm{H}), 7.50(\mathrm{~d}, J=8.7 \mathrm{~Hz}, 2 \mathrm{H})$, 7.69-7.73 (m, $2 \mathrm{H}), 8.55(\mathrm{dd}, J=8.0,1.2 \mathrm{~Hz}, 2 \mathrm{H}) ;{ }^{13} \mathrm{C} \mathrm{NMR}\left(\mathrm{CDCl}_{3}\right) 33.9,115.0,121.5,122.7$, 128.0, 134.0, 142.8, 178.3; IR $\left(\mathrm{CDCl}_{3}\right) 2917,2850,1637 \mathrm{~cm}^{-1}$; HRMS m/z 209.0843 (calcd for $\mathrm{C}_{14} \mathrm{H}_{11} \mathrm{NO}, 209.0841$ ).

\section{Supplementary Material}

Refer to Web version on PubMed Central for supplementary material.

\section{Acknowledgements}

We gratefully acknowledge the financial support of this work by the National Institutes of Health Kansas University Chemical Methodologies and Library Development Center of Excellence (P50 GM 069663).

\section{References}

1. Cardona ML, Fernandez MI, Pedro JR, Serrano A. Phytochemistry 1990;29:3003.

2. For a recent review on naturally-occurring xanthones, see: (a) Peres V, Nagem TJ, Faustino de Oliveira F. Phytochemistry 2000;55:683. [PubMed: 11190384] (b) Schwaebe MK, Moran TJ, Whitten JP. Tetrahedron Lett 2005;46:827. (c) Kenji M, Yukihiro A, Hong Y, Kenji O, Tetsuro I, Toshiyuki T, Emi K, Munekazu I, Yoshinori N. Bioorg Med Chem 2004;12:5799. [PubMed: 15498656] (d) Pedro M, Cerqueira F, Sousa ME, Nascimento MSJ, Pinto M. Bioorg Med Chem 2002;10:3725. [PubMed: 12413829] 
3. (a) Mahabusarakam W, Nuangnaowarat W, Taylor WC. Phytochemistry 2006;67:470. [PubMed: 16310231] (b) Gnerre C, Thull U, Gailland P, Carrupt PA, Testa B, Fernandes E, Silva F, Pinto M, Pinto M, Wolfender JL, Hostettmann K, Cruciani G. Helv Chim Acta 2001;84:552.

4. Poondru S, Zhou S, Rake J, Shackleton G, Corbett TH, Parchment R, Jasti BR. J Chrom B 2001;759:175. and references therein

5. (a) Grover PK, Shah GD, Shah RC. J Chem Soc 1955:3982. (b) Quillinan AJ, Scheinmann F. J Chem Soc, Perkin Trans 1973:1329. (c) Jackson WT, Robert JB, Froelich LL, Gapinski DM, Mallett BE, Sawyer JS. J Med Chem 1993;36:1726. [PubMed: 8389876] (d) Familoni OB, Ionica I, Bower JF, Snieckus V. Synlett 1997:1081. (e) Hassal CH, Lewis JR. J Chem Soc 1961;2:2312.

6. (a) Tabarrini O, Manfroni G, Fravolini A, Cecchetti V, Sabatini S, De Clercq E, Rozenski J, Canard B, Dutartre H, Paeshuyse J, Neyts J. J Med Chem 2006;49:2621. [PubMed: 16610805] and references therein (b) Taraporewala IB, Cessac JW, Chanh TC, Delgado AV, Schinazi RF. J Med Chem 1992;35:2744. [PubMed: 1495008] (c) MacNeil SL, Wilson BJ, Snieckus V. Org Lett 2006;8:1133. [PubMed: 16524286] (d) Harrison RJ, Reszka AP, Haider SM, Romagnoli B, Morrell J, Read MA, Gowan SM, Incles CM, Kellandc LR, Neidle S. Bioorg Med Chem Lett 2004;14:5845. [PubMed: 15501053]

7. (a) Nishio R, Wessely S, Sugiura M, Kobayashi S. J Comb Chem 2006;8:459. [PubMed: 16827555] (b) Goodell JR, Madhok AA, Hiasa H, Ferguson DM. Bioorg Med Chem 2006;14:5467. [PubMed: 16713270]

8. For a recent review, see: (a) Sander W. Acc Chem Res 1999;32:669. (b) Wittig G. Naturwissenschaften 1942:696.

9. Roberts JD, Semenow DA, Simmons HE Jr, Carlsmith LA. J Am Chem Soc 1956;78:601.

10. (a) Huisgen R, Sauer J. Angew Chem 1960;72:91. (b) Biehl ER, Nieh E, Hsu KC. J Org Chem 1969;34:3595. (c) Bunnett JF, Kim JK. J Am Chem Soc 1973;95:2254.

11. (a) Wittig G, Pohmer L. Chem Ber 1956;89:1334. (b) Wittig G. Org Synth 1963;IV:964.

12. Sapountzis I, Lin W, Fischer M, Knochel P. Angew Chem, Int Ed 2004;43:4364.and references therein 13. Himeshima Y, Sonoda T, Kobayashi H. Chem Lett 1983:1211.

14. Yoshida H, Shirakawa E, Honda Y, Hiyama T. Angew Chem, Int Ed 2002;41:3247.

15. Liu Z, Larock RC. J Am Chem Soc 2006;128:13112. [PubMed: 17017791]

16. Tambar UK, Stoltz BM. J Am Chem Soc 2005;127:5340. [PubMed: 15826170]

17. Zhao J, Larock RC. Org Lett 2005;7:4273. [PubMed: 16146405]

18. Liu Z, Larock RC. Org Lett 2004;6:99. [PubMed: 14703360]

19. (a) Alonso F, Beletskaya IP, Yus M. Tetrahedron 2005;61:11771. (b) Nicolaou KC, Bulger PG, Sarlah D. Angew Chem, Int Ed 2005;44:4442. (c) Negishi E. Handbook of Organopalladium Chemistry for Organic Synthesis 2002;1:1223.and references therein(d)TsujiJPalladium Reagents and Catalysts2004John Wiley \& SonsEngland135

20. Tofi M, Georgiou T, Montagnon T, Georgios V. Org Lett 2005;7:3347. [PubMed: 16018657]

21. Shah STA, Khan KM, Fecker M, Voelter W. Tetrahedron Lett 2003;44:6789. and references therein 22. Yoon K, Ha SM, Kim K. J Org Chem 2005;70:5741. [PubMed: 15989364] 


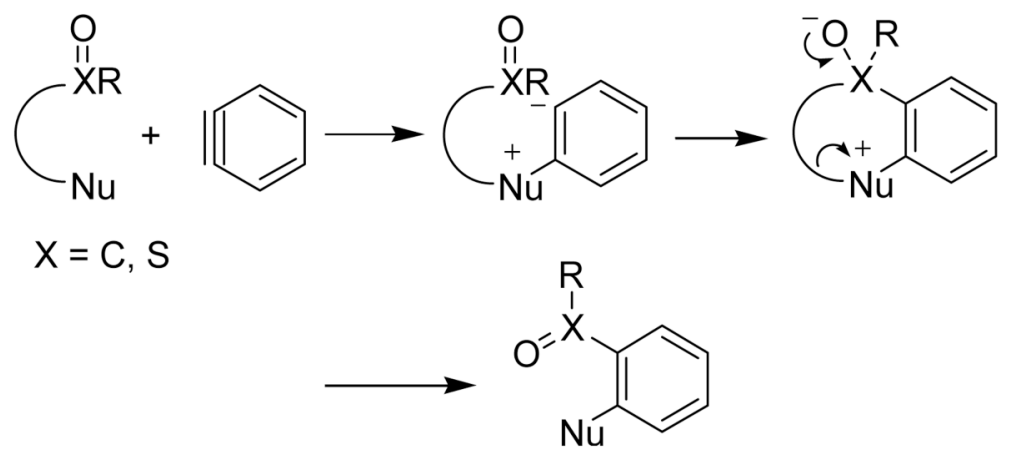

Scheme 1.

Aryne Insertion Reactions. 


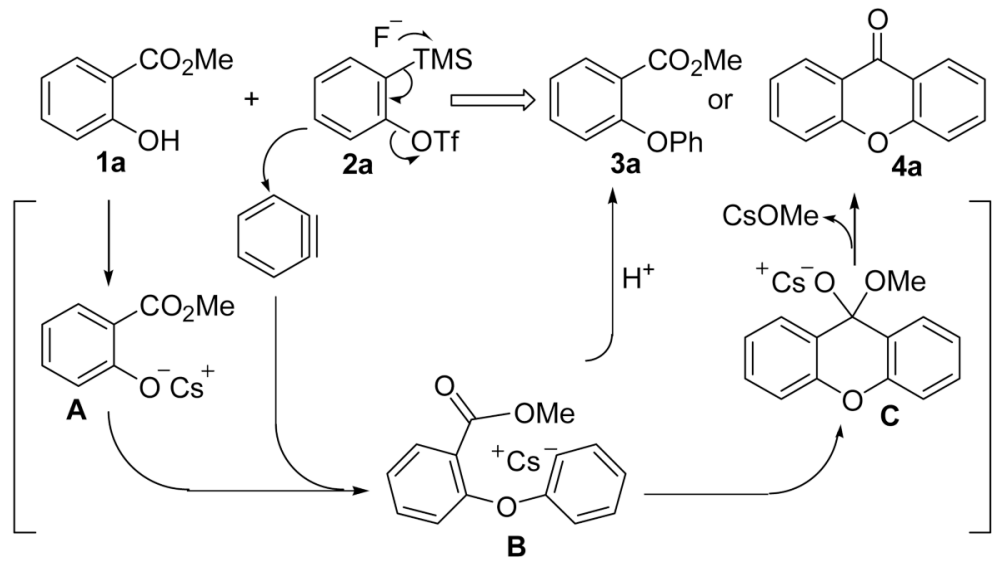

Scheme 2. 


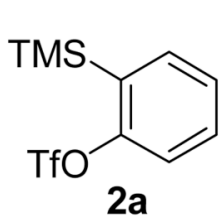<smiles>COc1cccc(O)c1S(C)(=O)=O</smiles><smiles>COc1cc(OC)c(S(C)(=O)=O)cc1OC</smiles><smiles>Cc1cc(O)c(S(C)(=O)=O)cc1C</smiles>

2d<smiles>CCCOc1ccc(C)cc1S(C)(=O)=O</smiles><smiles>CS(=O)(=O)c1cc2c(cc1O)CCC2</smiles>

Scheme 3.

Aryne Precursors. 


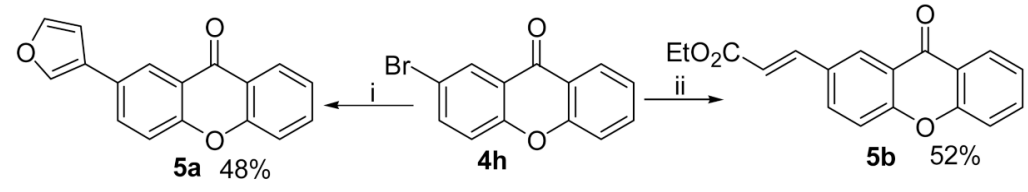

(i) $5 \% \mathrm{Pd}\left(\mathrm{PPh}_{3}\right)_{4}, 1 \mathrm{Na}_{2} \mathrm{CO}_{3}, 1: 4 \mathrm{MeOH} / \mathrm{Toluene}, 80^{\circ} \mathrm{C}, 12 \mathrm{~h}$; (ii) $5 \% \mathrm{Pd}(\mathrm{OAc})_{2}$, $2 \mathrm{NaHCO}_{3}, 1 \mathrm{TBAC}, \mathrm{DMF}, 100{ }^{\circ} \mathrm{C}, 24 \mathrm{~h}$.

Scheme 4.

Diversification of Halogen-substituted Xanthones. 


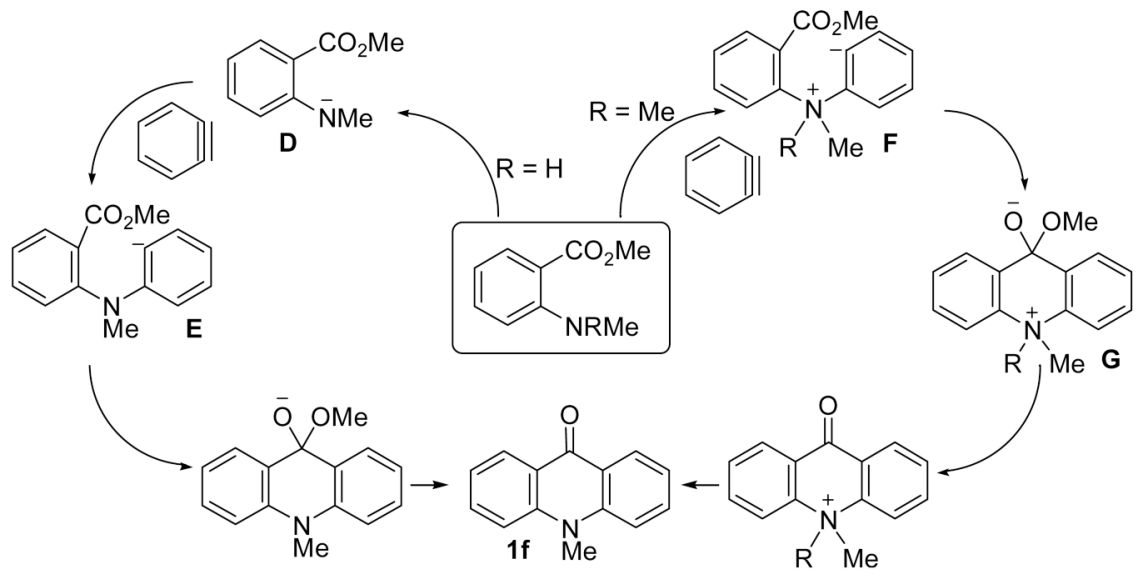

Scheme 4.

Plausible Mechanism for the Acridone Synthesis. 


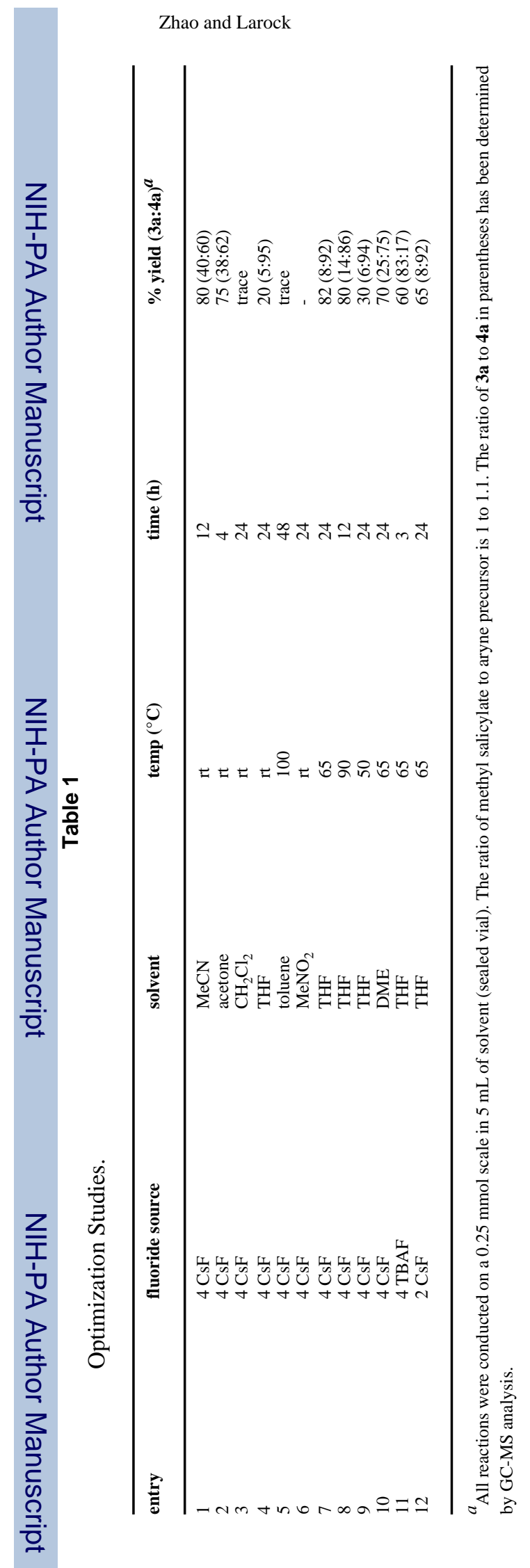

Page 13 


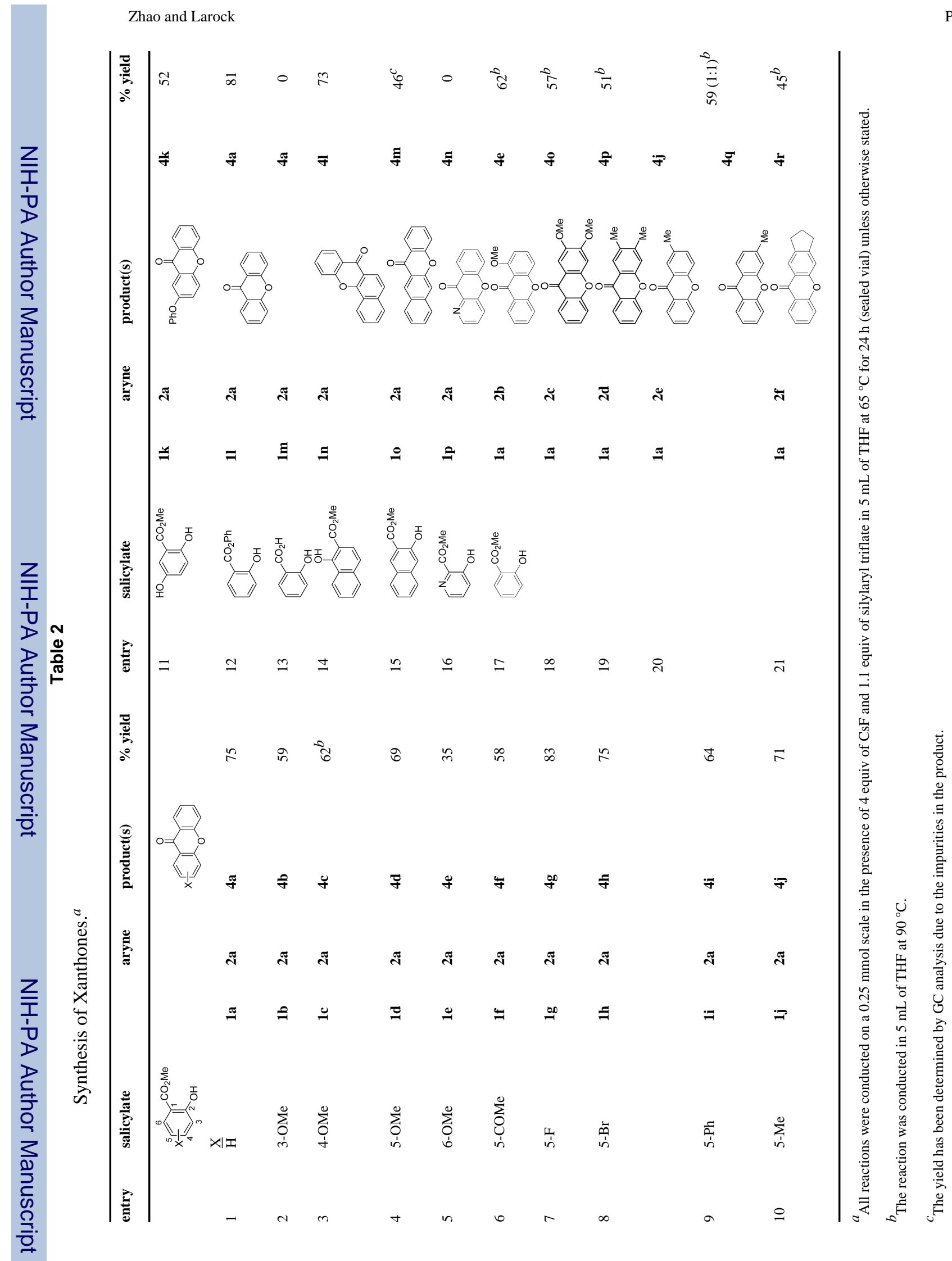

J Org Chem. Author manuscript; available in PMC 2008 September 5. 


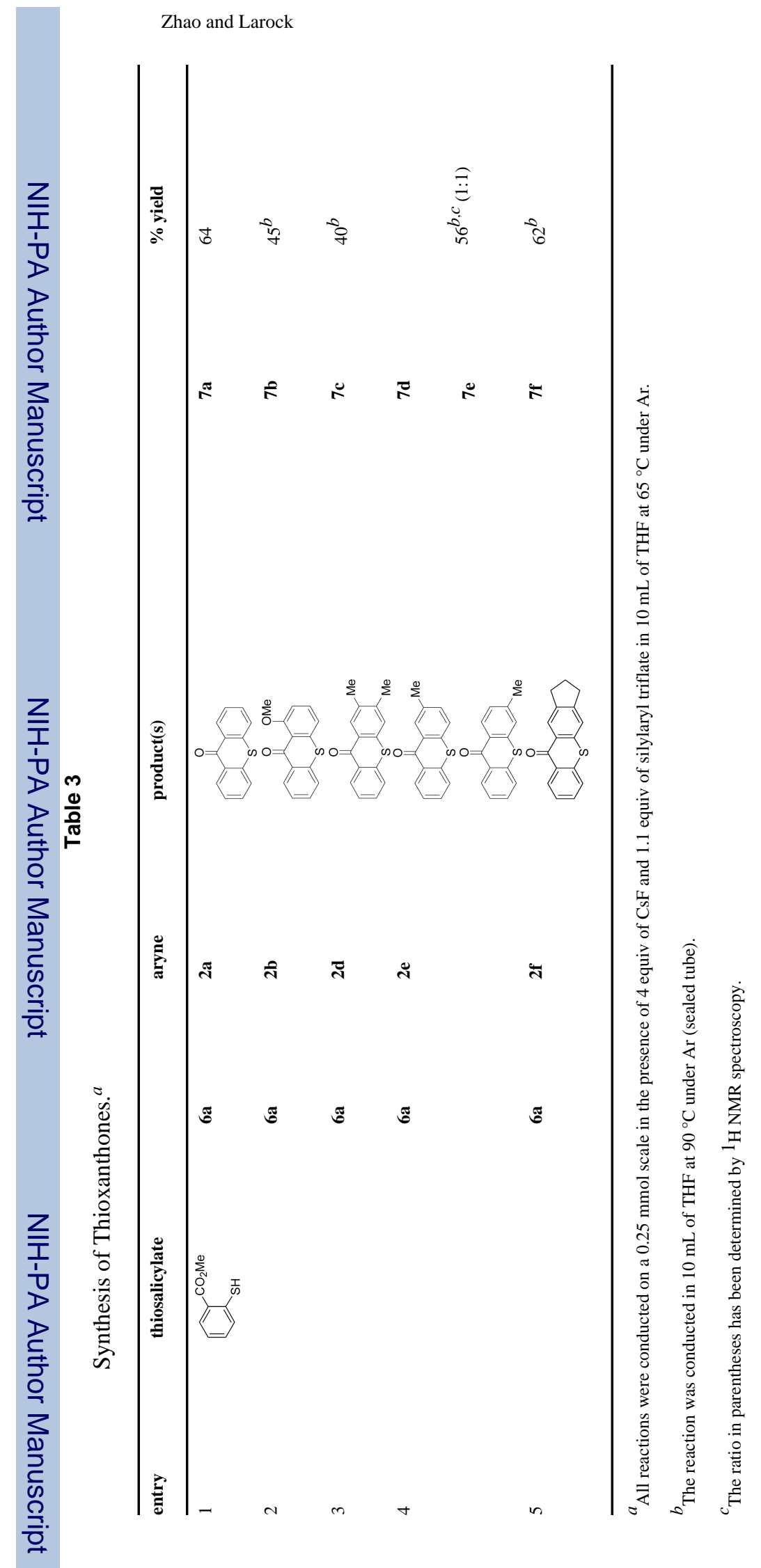

J Org Chem. Author manuscript; available in PMC 2008 September 5. 


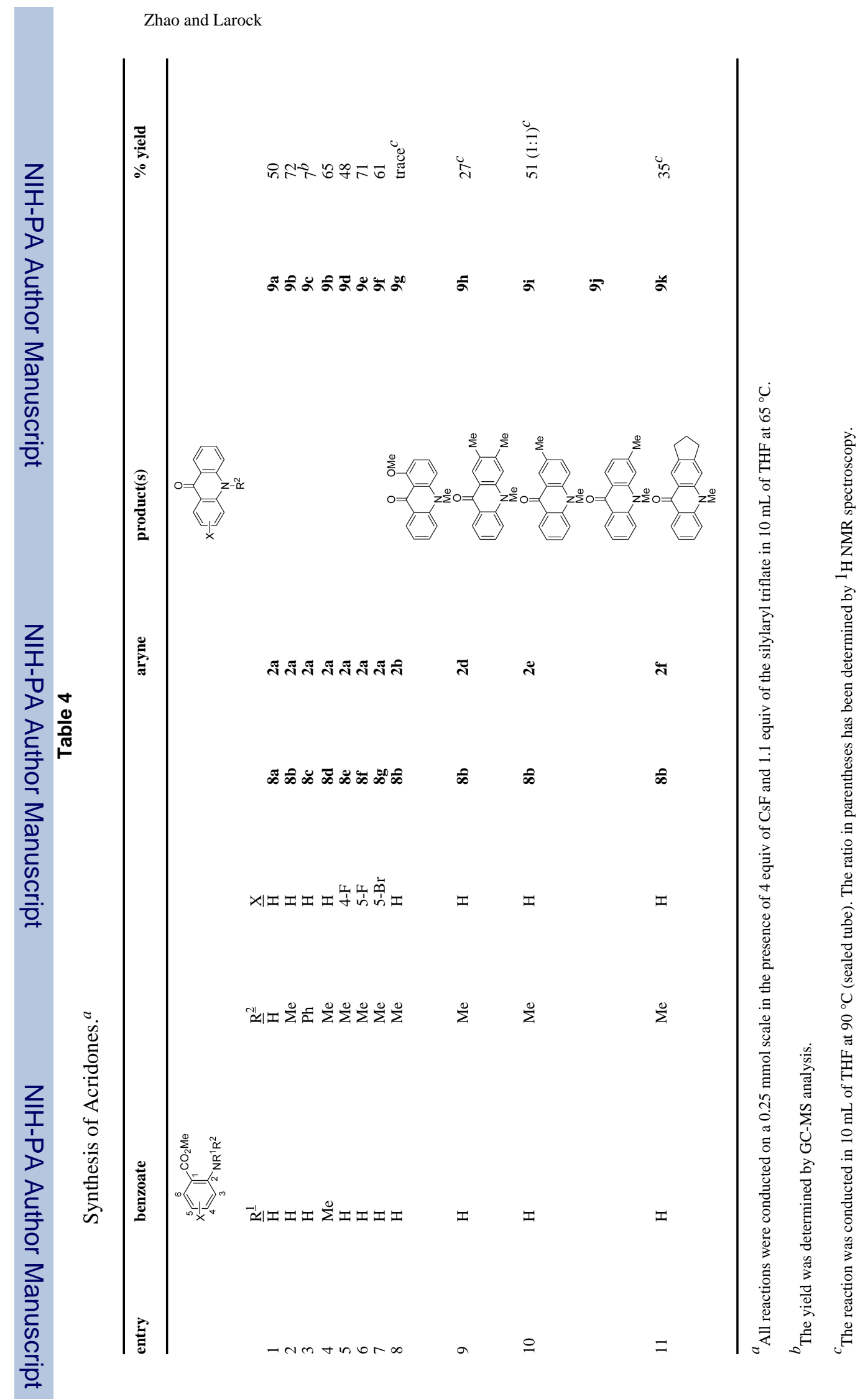

Page 16 